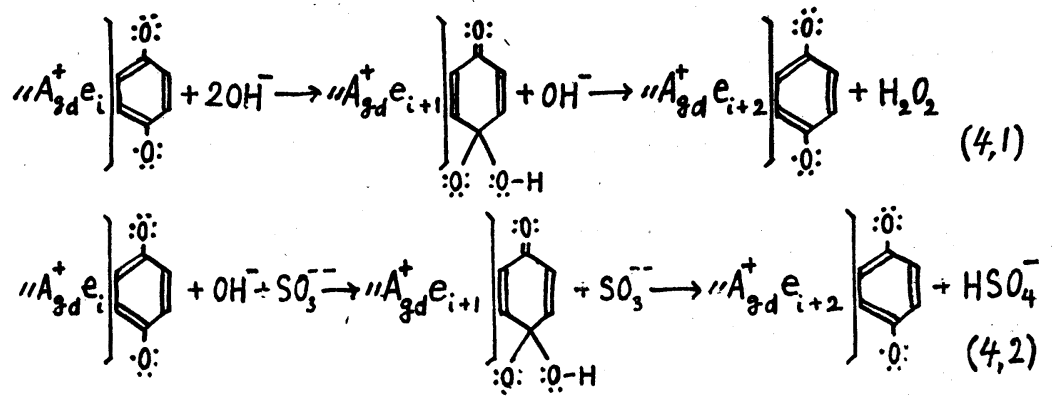

考える必要のない舆所を見出すことができる。

最後にもっとも重要な点であるが，式 $(3,2)(3,3)$ $(4,1)(4,2)$ ではセミキノンが再生されて吸着したまま その位置にとどまり，消耗されるのは $\mathrm{OH}^{-}$と $\mathrm{SO}_{3}{ }^{2-}$ とであることをとくに注意せ权ばならない。すなわち現 像反応の能率化がここに二分子反応の連鎖として起って その速度を大にしていると考えずにおられない*。

以上パラの位置に水酸基のあるものを代表として論究 を進めたのであるが，オルりの位置またアミノ基をかわ りに含むものでも同様の反応機構が推定され得る。また 最後に周知のように，レ・゙ルシンが相当の還元力をもち ながら現像に使用され双理由を，上述の中間生成物(I)

* 化学現像で生成する銀がフィラメント状に伸びる場合に対する説 明は, この烈しいと想像される斬鎖反応と他の諸事項とを関連せ しめてつぎの稿で竍みようと思う。
のようなものの構造上つくられ得ないためであるとする こともできるのは興味深いとてろである。

\section{結訔}

要するにベンゼン誘導体からなる現像主薬ならびにそ の他の成分のハロゲン化銀粒子にたいする反応は，生成 する銀の形態, $\mathrm{Br}^{-}$溶正の形式など 不明の点多く，そ の複雑さのため解決至難な問題である。けれども，その 界面現象に関する限りでは，少なくとも現像核としての 光分解銀表面にセ之キノンの関与した主薬の吸着があ り，それが触媒的に働らく二分子反応の連鎖を仮定すれ ば，きわめて自然にての高速度である化学現像反応の過 程が説明され得ることを指摘したい。

最後に，上述の説明のための仮定には矯激を避けたつ もりであるが，錯誤なく問題の真相に多少とも近より得 たとすれば幸宽と思らのである。

（日本大学工学部工業化学教室, 東京都千代田区）（昭和 30 年 9 月 7 日受理）

\title{
カラス貝脂肪性物質より新 $\Delta^{5,7}$ ・ステリンの分離
}

\author{
松 本 太 郎・田 村 利 武
}

4587ーステリンの存在については多くの文献があるが， 中でも貝類に関するものが多い。著者の一人（松本）は 外山氏11) とシジミよりコルビステリンを単離したが，乙 れはその後 $4^{5,7,22}$-ステリン $\left(\mathrm{mp} 151^{\circ} \sim 152^{\circ} \mathrm{C}\right.$, 酩酸工 ステルの $\left.\mathrm{mp} 152^{\circ} \sim 153^{\circ} \mathrm{C}\right)^{2)}$ であることが報告されて いる。Boer ら ${ }^{3)}$ は海産巻貝タマキビの一種 Littorina

1) 松本, 外山, 本誌 64, 326 (1943),

2) 外山, 喜多, 田中, Bull. Chem. Soc. Japan 25, 355 (1952).

3) A. G. Boer, E. H. Reerink, A. van Wijk, J. van Niekerk, Proc. Acad. Sci. Amsterdam 39, 622 (1936); U. S. Patent $2,216,719$. lettorea からプロビタミンD (mp $137^{\circ} \sim 137.5^{\circ} \mathrm{C}$, 酢 酸エステルの mp $135^{\circ} \sim 136^{\circ} \mathrm{C}$ ) を単離しているが, こ のステリンは Kind, Herman4) によると 7-デヒドロ クリオナステリンである。 Petering, Waddell5) はイ ガイに似た海産二枚貝 Modiolus demissus よりプロ ビタミン $\mathrm{D}\left(\mathrm{mp} 125.5^{\circ} \sim 127^{\circ} \mathrm{C}\right.$, 醀酸エステル $\mathrm{mp}$ $\left.137.5^{\circ} \sim 138.5^{\circ} \mathrm{C}\right)$ を分離し $\mathrm{C}_{29}$-ステリンであると発表

4) C. A. Kind, S. C. Herman, J. Org. Chem. 13, 867 (1948).

5) H. G. Petering, J. Waddell, J. Biol. Chem. 191, 765 (1951). 
している。また海産二枚貝ムラサキイガイ（Mytilus edulis) には 45,7,22-コレスタトリエノール6), リンゴマ イマイ Helix pomatia7) およびナメクジ Arion empiricotium ${ }^{7)}$ にはエルゴステリン, 海産巻貝エゾバイの 一種 Buccium undatum? 流 7-デヒドロコレステ リンが存在すると考えられているが，後二者は貝類以外 にも広く存在するてとがよく知られている。その他の天 然 $4^{5,7}$-ステリンとしては麦角の 22-ジヒドロエルゴス テリン8)および酵母の $24(28)$-デヒドロエルゴステリン9 が知られている。

著者ら ${ }^{10)}$ はさきに淡水産貝類数種の $\Delta^{5,7}$-ステリンに ついてしらべ，その中カラス貝などには少なくとも 2 種 類の $\Delta^{5,7}$-ステリンが含まれているととを報告したが， 今回さらにカラス貝を多量に入手しクロマトグラフィー によって $\Delta^{5,7}$-ステリンの分離を試みたとてろ，既知天 然ステリンのいずれとも異なるステリンを単離するてと ができた。てのステリンおよびその誘導体の性状はつぎ に示すように Linsert ${ }^{11)}$ の合成した 7-デヒドロスチグ マステリンおよびその誘導体の性状によく一致している ので両ステリンはおそらく同一物と考えられる。

\begin{tabular}{|c|c|c|c|c|c|}
\hline & \multicolumn{2}{|c|}{ ステリン } & \multicolumn{2}{|c|}{ 酢酸エステル } & \multirow{2}{*}{\begin{tabular}{|l}
$\begin{array}{c}\text { 安息香酸 } \\
\text { エスデ }\end{array}$ \\
融点 $\left({ }^{\circ} \mathrm{C}\right)$
\end{tabular}} \\
\hline & $\begin{array}{l}\text { 融点 } \\
\left({ }^{\circ} \mathrm{C}\right)\end{array}$ & {$[\alpha]_{\mathbf{D}}$} & $\begin{array}{l}\text { 融点 } \\
\left({ }^{\circ} \mathrm{C}\right)\end{array}$ & {$[\boldsymbol{\alpha}]_{\mathrm{D}}$} & \\
\hline $\begin{array}{l}\text { カラス貝のステ } \\
\text { リン }\end{array}$ & $\begin{array}{l}153 \\
\sim 154\end{array}$ & $-114^{\circ}$ & $\begin{array}{l}172 \\
\sim 173\end{array}$ & $-79^{\circ}$ & $(175 \sim 17 \stackrel{*}{6})$ \\
\hline $\begin{array}{l}7 \text { ーデヒドロスチ } \\
\text { グマステリン11) }\end{array}$ & 154 & $-113^{\circ}$ & 172 & - & 180 \\
\hline
\end{tabular}

\section{実 験 の 部}

長野県諏訪湖産のカラス貝 Cristaria spatiosa $33 \mathrm{~kg}$ （貝 80 個，その内䒬の重量 $11.0 \mathrm{~kg}$ ）を剝身とし(21.5 $\mathrm{kg}) 80^{\circ} \mathrm{C}$ 内外の乾燥器に入れやや乾燥した時これを細 断し，エーテルーエチルアルコールにて浸漬し,さらにエ 一テルで抽出して腤褐色半国状の脂肪性物質 $145 \mathrm{~g}$ を得 る。抽出残査はさらに乾燥すると $1.4 \mathrm{~kg}$ となるので, 脂肪性物質は乾燥剝身の $9.4 \%$ にあたる。

* 融点は再結晶によってさらに上昇の傾向にある.

6) van der Vliet, Rec. trav. chim. 67, 265 (1948).

7) F. Bock, F. Wetter, Z. Physiol. Chem. 256, 33(1938).

8) A. S. Rniz, Anales real Acad. farm. 3, 201 (1943); Chem. Abst. 38, 503 (1944).

9) O. N. Breivik, J. L. Owades, R. J. Light, J. Org. Chem. 19, 1734 (1954).

10) 松本, 田村, 伊藤, 本誌 76, 953 (1955).

11) O. Linsert, Z. Physiol. Chem. 241, 125 (1936).
ての脂肪性物筫を 䇪素気流中で $1 \mathrm{~N}$ 水酸化カリウム一 エチルアルコールにてケン化し, 不ヶン化物をエーテル 抽出すると暗橙黄色固状物 $38.5 \mathrm{~g}$ (脂肪性物筫に 対し て $26.5 \%$ ) が得られる。との不ケン化物のエチルアル コール溶液の紫外部吸収スペクトルは第 1 四の通りであ

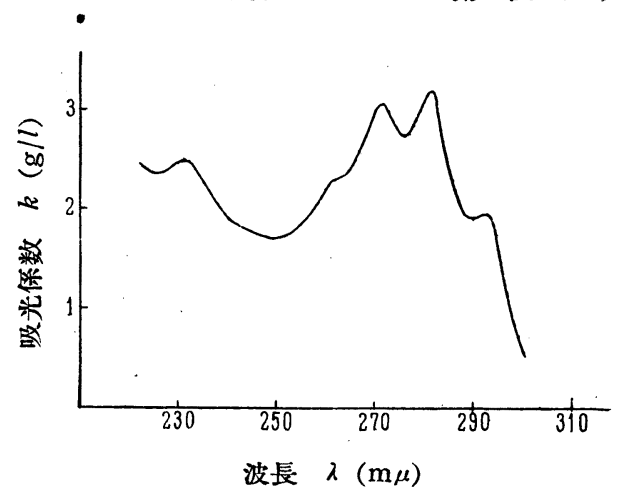

第 1 図 不ケン化物の吸収スペクトル

る (吸光係数 $(\mathrm{g} / l) k_{232} 2.4, k_{262} 2.3, k_{272} 3.1, k_{282}$ $3.2, k_{293} 1.95$ 以上極大)。さらに不ケン化物 $0.503 \mathrm{~g}$ のエチルアルコール $(90 \%)$ 溶液に $1 \%$ ジギトニンーエ チルアルコール $(90 \%)$ 溶液を加えると $0.856 \mathrm{~g}$ のジ トニド（ステリンとして 43.0\%）が得られる。とのジ ギトニドのエチルアルコール溶液の紫外部吸収スペク トルは第 2 困のように $4^{5,7}$-ステリン特有の吸収を示 し，45,7ーステリンの量10)は不ケン化物の $13.0 \%$ である $\left(k_{282}\right.$ 0.990)。

この不ケン化物はアセトンーメチルアルコール $(1: 1)$ 汃再結晶すると $\mathrm{mp} 135^{\circ} \sim 139^{\circ} \mathrm{C},[\boldsymbol{\alpha}]_{\mathrm{D}}^{16}=-40^{\circ}$ を 示す結晶 $15.5 \mathrm{~g}$ となる。乙れを咥素気流中で無水酶酸

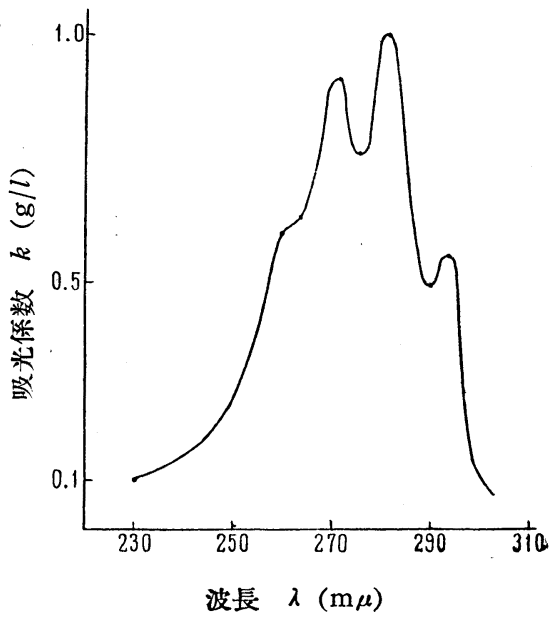

第 2 図 ジギトニドの吸収スペクトル 


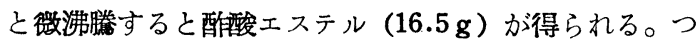
ぎにてれをさらにアャトンーメチルアルコールで反覆分 別結晶するとつぎのような区分が得られる。

\begin{tabular}{lr|c|c|c}
\hline \hline 区 & 分 & $\mathrm{I}$ & I & II \\
\hline 収 & 量 $(\mathrm{g})$ & 5 & 2.5 & 4 \\
融 & 点.$\left({ }^{\circ} \mathrm{C}\right)$ & $135 \sim 137$ & $125 \sim 126$ & $110 \sim 117$ \\
$\Delta^{5,7}$ ス リン $(\%)$ & 9 & 12 & 13 \\
{$[\alpha]_{\mathrm{D}}$} & & $-44^{\circ}$ & $-42^{\circ}$ & $-38^{\circ}$ \\
\hline
\end{tabular}

区分Iのステリン酸エステル $1.5 \mathrm{~g}$ はノルマルヘキ サンーベンゼン $(6: 1) 20 \mathrm{cc}$ にとかして酸化アルミニ ウム（ブロックマン） $50 \mathrm{~g}$ を用いた吸着塔（径 $1.5 \mathrm{~cm}$, 長 $30 \mathrm{~cm}$ ) に吸着させ,さらに同一の溶剂を加えて吸着層 を展開し逐次流出する溶液を一定量ずつ分取する。分取 した溶液より溶剤を留去してステリン醀酸エステルを回 収する。てのようにして分別されたステリン䣲酸エステ ルおよび遊離ステリンは第 1 表のようである。

\section{第 1 表}

ステリン酶酸エステル $(1.5 \mathrm{~g})$

\begin{tabular}{r|c|c|c}
\hline 流出溶液 $(\mathrm{cc})$ & 収 & 量 $(\mathrm{g})$ & $4^{5}, 7$ ステリン $(\%)$ \\
\hline 100 & 0.90 & 0 \\
50 & 0.2 & 6 \\
50 & 0.11 & 12 \\
50 & 0.05 & 23 \\
100 & 0.01 & 48 \\
600 & 0.04 & 90 \\
$400^{*}$ & 0.05 & 30 \\
$400^{*}$ & 0.01 & 0 \\
\hline
\end{tabular}

遊離ステリン $(1.5 \mathrm{~g})$

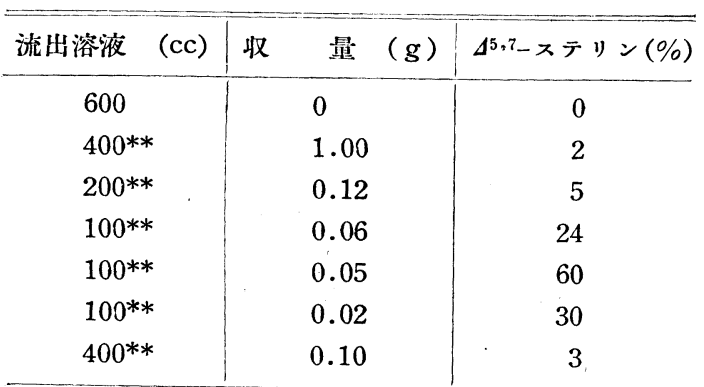

* はベンゼンーメチルアルコール $(10: 1)$.

** はノルマルへキサンーベンゼシーメチルアルコ ール $(50: 50: 1)$.

このような分別を 3 回行って, $90 \%$ 内外の $4^{5,7}$ ーステ リンを含むステリン酩酸エステル $0.12 \mathrm{~g}$ 得た。これを

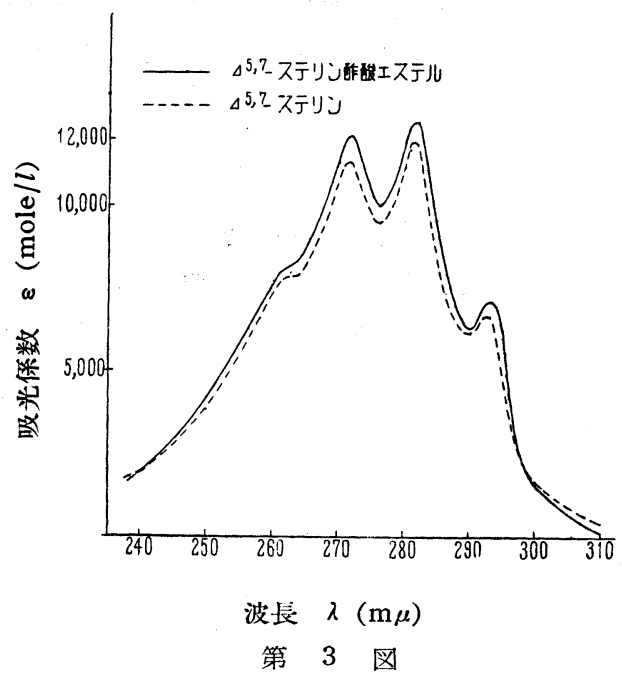

さらにアセトンーメチルア.ルコールより再結晶すると $\mathrm{mp}$ $153^{\circ} \sim 155^{\circ} \mathrm{C}$ となり，なお数回再結晶を繰返えすと融 点は一定してさらにアセトン, エチルアルコールおよび 酩酸ークロロホルムより再結晶しても融点に変化がない。 また再結晶母液からの第 2 結晶も同じ融点を示す。

$\operatorname{mp} 172^{\circ} \sim 173^{\circ} \mathrm{C}, \quad[\alpha]_{\mathrm{D}}^{30}=-79^{\circ}$

この結晶の紫外部吸収スペクトル（エチルアルコール 溶液) の吸光係数は $\varepsilon_{272} 12,105, \varepsilon_{282} 12,590, \varepsilon_{293} 7170$ である。分子量 (Rast 法) $455\left(\mathrm{C}_{31} \mathrm{H}_{48} \mathrm{O}_{2}\right.$ としての計 算值 452.7)。

分析 実测値 C $82.45 \%, H ~ H ~ 11.07 \%$ $\mathrm{C}_{31} \mathrm{H}_{48} \mathrm{O}_{2}$ としての

計算值 C $82.24 \%, \mathrm{H} 10.69 \%$

\section{遊離ステリン}

上記のステリン酰酸エステル $30 \mathrm{mg}$ を跮素気流中でケ ン化して遊離ステリンとなし,アセトンーメチルアルコー ルから再結晶すると $\mathrm{mp} 153^{\circ} \sim 154^{\circ} \mathrm{C},[\alpha]_{\mathrm{D}}^{28}=-114^{\circ}$, 収量 $15 \mathrm{mg}$ の針状結晶が得られる。てれはさらに溶郕 を变えて再結晶しても融点に変化なく，また母液からの 結晶も同一融点を示す。とのステリンの紫外部吸収スペ クトル测定の結果, 四光係数は $\varepsilon_{272} 11.320, \varepsilon_{282} 11970$, $\varepsilon_{293} 6750$ (エチルアルコール溶液) である。

\section{安息香酸エステル}

上記の遊離ステリン $5 \mathrm{mg}$ をピ.リジンにとかし塩化べ ンゾイルを加えて $60^{\circ} \mathrm{C}$ に 5 時間放置して生ずる生成物 はアセトンから再結晶すると $\mathrm{mp} 175^{\circ} \sim 176^{\circ} \mathrm{C}$ の板状 結晶となり，さらに再結晶によって融点が上昇すると思 われるが，陚料が微量となり再結晶を繰返えし得ない。 
この安息香酸エステルの紫外部吸収極大における吸収係 数は $\varepsilon_{234} 14000, \varepsilon_{272} 13300, \varepsilon_{282} 13500, \varepsilon_{293} 770$ であ る。

\section{総括}

カラス貝 Cristaria spatiosa (Clessin) の不ケン化 物結晶性成分をその酷酸エステルの分別結晶により難溶 部を分ち、乙れを酸化アルミニウムを用いたクロマトグ
ラフィーで $\operatorname{mp} 172^{\circ} \sim 173^{\circ} \mathrm{C}, \quad[\alpha]_{\mathrm{D}}=-79^{\circ}, \varepsilon_{282} 12590$ (遊離ステリンの $\mathrm{mp} 153^{\circ} \sim 154^{\circ} \mathrm{C},[\alpha]_{\mathrm{D}}=-114^{\circ}, \varepsilon_{292}$ 11970)の $4^{5,7}$ ーステリンを単㒕した。このステりンは天 然物から始めて分離されたもので 7-デヒドロスチグマ ステリン $\left(4^{5,7,22}-\mathrm{C}_{29}\right.$-ステリン $)$ およびその誘導体の性 状と一致している。

試料について御指導を得た科学博物館滰庸平氏扎よび 実験に援助を得た国馬一芳氏に感謝する。

\section{正誤訂 正}

○本誌 76, 第5 号. (1955) 表紙 2 上より 4 行目 䛊 正 横山裕之 横山祐之

○本誌 76, 第 10 号 (1955) 表紙 1 無機化学および 地球化学欄第 1 行目

誤

正

高木 進

高本 進

○本誌 76, 第 10 号 (1955) 欧文目次 2 下より 11 行目

誤 Yoshiharu Matubara and Minoru Morita

正 Yoshiharu Matubara, Minoru Morita, Shoji Wakabayashi and Yoshiteru Heya

○下田，本誌 76, 1249 (1955) 右祭第 2 㓙左の縦軸 の目盛は上より

䛊

1050

正

$\begin{array}{lll}1.0 & 0.5 & 0\end{array}$

○下田, 本誌 76, 1251 (1955) 左欄 21 行目

誤

正

磁賀県磁賀郡滋賀県滋賀郡!

○下田, 本誌 76, 1251 (1955) 左欄 25 行目

誤 正

別法で報告する 別報で報告する

○下田, 本誌 76, 1251 (1955) 左欄最下行

謂

正

および鉄が濃集し およびフッ素が濃集し

○下田, 本誌 76, 1252 (1955) 左闌上より 7 行目

誤

正

鉄が濃集し

フッ素が濃集し

○下田, 本誌 76, 1252 (1955) 左欄上より 8 行目

倸

正

酸化鉄および $\mathrm{OH}$ 酸化第一鉄および $\mathrm{OH}$

昭和 30 年 12 月 5 日 印 刷 昭和 30 年 12 月 10 日発行

[定価 150 円（送料 8 円)] 発行兼編集人 東京都千代田区(神田局区內)神田段河合 1 丁目 5 番地 岩 城広吉 印剧人東京都北区上中里町 1 の 35 倉沢值男 印刷所東京都北区上中里町 1 ○ 35 株式会社双交社 発 行 所 東京都千代田区(神田局区內)神田㯺河台 1 丁目 5 番地

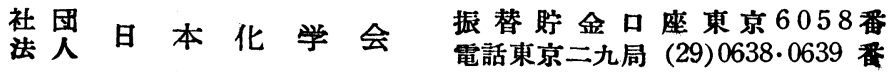

